\title{
Irrigation levels and use of hydro retainer polymer in greenhouse lettuce production
}

\author{
Welcio R. da Silva ${ }^{1}$, Leandro C. Salomão ${ }^{2}$, Débora R. M. Pereira ${ }^{3}$, Henrique F. E. de Oliveira ${ }^{1}$, \\ Alexandre I. de A. Pereira ${ }^{2} \&$ Fernando S. Cantuario ${ }^{2}$ \\ ${ }^{1}$ Instituto Federal Goiano/Programa de Pós-Graduação em Irrigação no Cerrado. Ceres, GO, Brasil. E-mail: welcio_rs@hotmail.com (Corresponding
author) - ORCID: 0000-0002-6673-7182; henrique.fonseca@ifgoiano.edu.br - ORCID: 0000-0001-8698-292X
${ }^{2}$ Instituto Federal Goiano. Urutaí, GO, Brasil. E-mail: leandro.salomao@ifgoiano.edu.br - ORCID: 0000-0001-9436-1488; aiapereira@yahoo.com.br -
ORCID: 0000-0001-7957-6691; fernandoscantuario@hotmail.com - ORCID: 0000-0002-8052-4861
${ }^{3}$ Prefeitura Municipal de Goianésia/Secretaria do Meio Ambiente. Goianésia, GO, Brasil. E-mail: deboraagronomia@gmail.com - ORCID: 0000-0003-
3751-0162
}

\begin{abstract}
One of the potential alternatives to improve the use of water resources is the use of hydro retainer polymer applied to the soil. The objective of this study was to evaluate how irrigation levels and doses of hydro retainer polymer interfere in the production of 'Vanda' lettuce. The experiment was carried out from December 2017 to January 2018 under protected environment in the Instituto Federal Goiano,

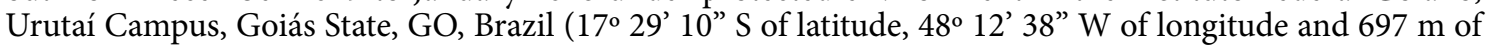
altitude). The work tested four irrigation levels of 50,75, 100 and $125 \%$ of the evaporation obtained daily by the hook micrometer and five doses of hydrogel polymer $\left(0,50,100,150\right.$ and $\left.200 \mathrm{~g} \mathrm{plant}^{-1}\right)$. The experimental design was a randomized block design in a scheme of split-plot and four blocks. Canopy fresh and dry mass, plant height, number of leaves and productivity were evaluated. There was $29.24 \%$ increase in the dry mass comparing the hydro retainer polymer doses of 0 and $169.28 \mathrm{~g}$ and an increase of $14.36 \%$ of the height of plants when compared with the irrigation levels of 50 and $125 \%$. The use of a hydro retainer polymer provided a significant increase in all the evaluated productive variables. The irrigation levels influence the fresh mass from aerial part, plant height and productivity. The productivity increased $18.42 \%$ for the irrigation levels used and the highest estimated values were presented in the dose of $157.49 \mathrm{~g}\left(14.46 \mathrm{t} \mathrm{ha}^{-1}\right)$ hydro retainer polymer.
\end{abstract}

Key words: hydrogel, Lactuca sativa L., water resources

\section{Níveis de irrigação e uso de hidrorretentor na produção de alface em ambiente protegido}

RESUMO: Uma das possíveis alternativas para potencializar a utilização de recursos hídricos é a utilização de polímeros hidrorretentores. Objetivou-se avaliar como níveis de irrigação e doses de solução hidrorretentora interferem na produção da alface crespa, cultivar Vanda. O experimento foi realizado de dezembro de 2017 a janeiro de 2018, sob canteiros em ambiente protegido na área experimental do Instituto Federal Goiano Campus Urutaí, GO (17²9’ 10" S de latitude, 48 12’ 38” O de longitude e $697 \mathrm{~m}$ de altitude). Testaram-se quatro níveis de irrigação $(50,75,100$ e $125 \%)$ da evaporação obtida diariamente pelo micrômetro de gancho e cinco doses de solução de hidrogel $\left(0,50,100\right.$ e 200 g planta $\left.^{-1}\right)$. Utilizou-se o delineamento de blocos ao acaso e esquema de parcelas subdivididas e quatro blocos. Foram avaliadas massa fresca da parte aérea, massa seca da parte aérea, altura de plantas, número de folhas e produtividade. Verificou-se incremento de $29,24 \%$ da massa seca da parte aérea comparando as doses de solução hidrorretentora de 0 e 169,28 g e acréscimo de $14,36 \%$ da altura de plantas quando comparados os níveis de irrigação de 50 e $125 \%$. O uso de solução hidrorretentora proporciona aumento significativo em todos os parâmetros produtivos avaliados. Os níveis de irrigação utilizados influenciam as variáveis massa fresca da parte aérea, altura de planta e produtividade. A produtividade aumentou $18,42 \%$ para os níveis de irrigação utilizados, e os maiores valores estimados foram com a dose de solução hidrorretentora de $157,49 \mathrm{~g}\left(14,46 \mathrm{t} \mathrm{ha}^{-1}\right)$.

Palavras-chave: hidrogel, Lactuca sativa L., recursos hídricos

Ref. 196626 - Received 27 Apr, 2018 • Accepted 09 Apr, 2019 • Published 30 Apr, 2019 


\section{INTRODUCTION}

Lettuce (Lactuca sativa L.) is characterized as an annual plant belonging to the Asteraceae family, one of the most consumed vegetables in Brazil and in the world. Since it is originated from a temperate climate, cultivation at high temperatures can reduce its cycle and produce smaller plants due to early tasseling function (Henz \& Suinaga, 2009).

The lettuce varieties in Brazil are of the crisphead group, which accounts for approximately $65 \%$ of the market, followed by varieties of the American (20\%), smooth (10\%) and the remaining 5\% (Suinaga et al., 2013).

The development of vegetables is strongly influenced by soil moisture conditions. The replenishment of soil water by irrigation systems is a decisive factor for the success of horticulture. Proper application of the irrigation depth promotes a gain in productivity and quality (Marouelli \& Silva, 1996; Silva \& Queiroz, 2013).

The expansion of the irrigated area and consequent increase in water demand could result in scarcity, thereby increasing the need to study alternatives to minimize wastage (Carvalho, 2017). Therefore, it is necessary to adopt irrigation management techniques that help in making the best decision (Salomão, 2012). In addition to management, one of the possible alternatives to optimize the use of water resources is the use of hydro retainer polymers.

The hydrogel is characterized by being a material capable of retaining large volumes of water without dissolving, and can store hundreds of times its weight in water, which is gradually released to the plants, favoring the possibility of increasing the irrigation interval (Mendonça et al., 2015; Navroski et al., 2015). The objective of this study was to evaluate how levels of irrigation and doses of hydro retainer polymer interfere in the production of the crisphead lettuce cultivar Vanda.

\section{Material AND Methods}

The experiment was carried out in the Educational Production Unit (EPU) of the Instituto Federal Goiano, Campus Urutaí, Goias state, Brazil (17² 29' 10" S latitude, $48^{\circ} 12^{\prime} 38^{\prime \prime} \mathrm{O}$ longitude and $697 \mathrm{~m}$ of altitude). The region is classified as having a tropical altitude climate, with dry winter and rainy summer, of type Cwb by the Köppen classification. The mean temperature is $23{ }^{\circ} \mathrm{C}$ and can reach, during the year, values below $15^{\circ} \mathrm{C}$ and maximum of $30^{\circ} \mathrm{C}$, with mean precipitation between 1000 and $1500 \mathrm{~mm}$ and mean relative humidity of $71 \%$.

The maximum, minimum and mean air temperatures recorded during the conduction of the experiment, within the protected environment, are expressed in Figure 1A and the mean relative humidity (RH) of the air is in Figure 1B. For this period, maximum temperatures ranged from 25 to 36.8 ${ }^{\circ} \mathrm{C}$, the minimum temperatures remained in the range of 17.3 to $21.7^{\circ} \mathrm{C}$ and the overall mean temperature was $26.46^{\circ} \mathrm{C}$. For the mean relative humidity (RH) of the air, the value of $69.18 \%$ was observed in the period of the experiment, and the extreme values were between 59 and $83.5 \%$.
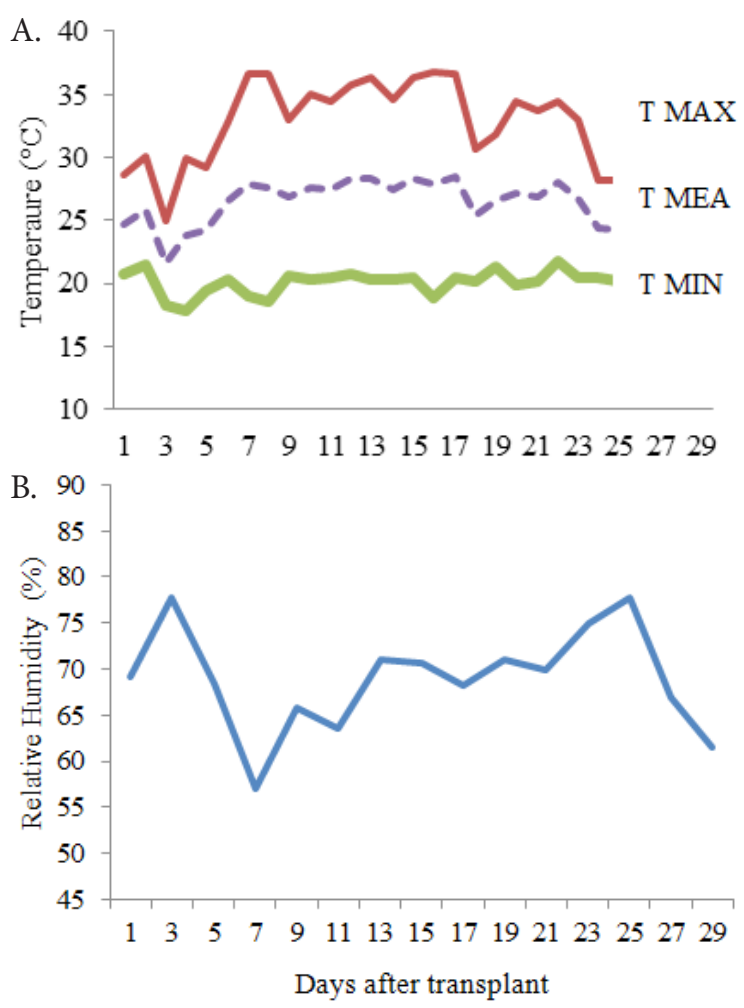

Figure 1. Maximum (TMAX), minimum (TMIN) and mean (TMEA) air temperatures (A) and mean relative air humidity (B) inside the protected environment

The soil of the experimental area has a sandy clay texture, having chemical characteristics of CTC of $10.59 \mathrm{cmol} \mathrm{dm}_{c}^{-3}$; $\mathrm{pH}$ of $5.8 ; 85.79 \%$ of base saturation; $7.5 \mathrm{cmol}_{\mathrm{c}} \mathrm{dm}^{-3}$ of calcium, $1 \mathrm{cmol}_{\mathrm{c}} \mathrm{dm}^{-3}$ magnesium, $193 \mathrm{mg} \mathrm{dm}^{-3}$ of potassium and $135 \mathrm{mg} \mathrm{dm}^{-3}$ of phosphorus, $15 \mathrm{mg} \mathrm{dm}^{-3}$ sulfur and $21 \mathrm{~g} \mathrm{dm}^{-3}$ of organic matter.

The experiment was carried out between December 2017 and January 2018 in a greenhouse of the simple arc type, EastWest orientation, with dimensions of $7 \mathrm{~m}$ wide by $30 \mathrm{~m}$ in length, covered with a selective plastic film, Suncover AV Blue ${ }^{\circ}$.

A drip irrigation system was used, adopting a lateral line for two plant lines, with emitters spaced apart at $0.2 \mathrm{~m}$, flow rate of $1.5 \mathrm{~L} \mathrm{~h}^{-1}$ and at a working pressure of 10 m.w.c. The pumping system consisted of a $1 \mathrm{hp}$ motor pump assembly. A disc filter with holes of $1.25 \times 10^{-4} \mathrm{~m}$ (120 mesh) of aperture, registers and manometer were used.

For the experiment, a randomized block design was used with subdivided plot and four blocks, in which four levels of irrigation were used (50, 75, 100 and $125 \%$ of the evaporation obtained daily from the Class A tank), and five doses of hydrogel solution $\left(0,50,100,150\right.$ and $\left.200 \mathrm{~g} \mathrm{plant}^{-1}\right)$. In this scheme, each irrigation level corresponded to a plot and, each dose, to a subplot. Irrigation levels were calculated according to the crop requirement, based on the daily water evaporation of the Class A tank (EV) installed inside the protected environment, adopting a day irrigation interval.

In preparation of the solution, $100 \mathrm{~g}$ of the Hydrogelforth $\mathrm{Gel}^{\circ}$ was diluted with $10 \mathrm{~L}$ of water, left standing for $15 \mathrm{~min}$, according to the manufacturer instructions. In order to perform the transplant, small pits were opened on the surface of the beds, where the respective doses of the solution were 
deposited. The beds were $1 \mathrm{~m}$ wide by $20 \mathrm{~m}$ long, with 0.5 $\mathrm{m}$ between beds. The material was covered with soil and the seedlings were inserted in the range, above the hydrogel.

A spacing of $0.25 \times 0.25 \mathrm{~m}$ between rows and plants was used. For each dose (subplot), equivalent to 16 plants were used, and only the four central plants were considered for analyses.

Soil preparation was carried out with mechanized plowing by means of a microtractor (YanmarAgritech TC-14). Subsequently, the beds were made manually with the aid of hoes.

The planting and topdressing fertilization were performed by fertirrigation following the recommendations of Trani et al. (2014). This management was performed by means of a negative pressure system with the aid of a venturi-type injector. This operation was performed at weekly intervals.

The seedlings were acquired from a commercial nursery at the age of 30 days post-emergence. The cultivar used was 'Vanda' of the Crisphead group, with an early cycle, that can be harvested at 55 days after emergence, has large leaves, vigorous root system, high resistance to edge burning and lettuce mosaic virus (Lettuce mosaic virus, LMV-II), besides being adapted for varying temperature conditions.

According to Sala \& Costa (2012), the cultivar Vanda is among the materials that were created to meet the demand of new cultivars of crisphead lettuce with slow tasseling, large plant size and associated resistance to lettuce mosaic virus (LMV) and mildew (Bremia lactucae).

The irrigations had a fixed irrigation interval of one day and were performed early in the morning $(8 \mathrm{~h})$. The differentiation between the treatments of irrigation depths were given from the $10^{\text {th }}$ day after transplantation (DAT).

The irrigation levels were calculated according to evaporation data $(\mathrm{EV})$, and for the calculation of irrigation time, the methodology presented by Santos \& Pereira (2004) was used. The crop coefficient (Kc) used was determined according to the development stage. For phases I, II, III and IV the Kc values were $0.85 ; 0.90 ; 1.00$ and 0.95 , respectively (Trani et al., 2011).

In the center of the protected environment, a meteorological shelter was built, made of wood, painted white and positioned at a height of $1.5 \mathrm{~m}$. A digital hygrometer was installed in this shelter, in which the data of maximum and minimum temperatures and relative humidity were collected. From these data, daily mean values were calculated for the entire period of the experiment.

The temperature values found were relatively low for the locality and time of the year. These results can be attributed to the selective plastic film used in the coverage of the protected environment, Suncover AV Blue ${ }^{\varpi}$, which is a blue plastic consisting of five layers, with the ability to select the wavelengths of the radiation and thereby reduce the internal temperature of the environment.

According to Trani et al. (2014), the most suitable temperatures for the crop are between 15 and $20^{\circ} \mathrm{C}$. However, according to Filgueira (2008), over the years, breeders have developed cultivars adapted to the spring and summer seasons, resistant to early tasseling. The minimum air temperature tolerated by the lettuce is $6^{\circ} \mathrm{C}$ and the maximum is $30^{\circ} \mathrm{C}$.
The harvest was performed at 29 days after transplantation (DAT), this being the point at which the plants reached maximum vegetative development, as described by Trani et al. (2014). The aerial part was weighed and placed in paper bags, and were placed in an oven with air renewal and forced circulation at $65^{\circ} \mathrm{C}$, until they reached constant mass.

The following variables were analysed: fresh mass of aerial part (FMAP, g) and dry mass of aerial part (DMAP, g) with a digital scale with an accuracy of $0.01 \mathrm{~g}$; plant height $(\mathrm{H}, \mathrm{cm})$, number of leaves (NL) and yield (PRO, $\mathrm{t} \mathrm{ha}^{-1}$ ), considering a population of 96000 plants ha-1. Soil moisture (gravimetric) was determined in the layer $0-20 \mathrm{~cm}$.

An exploratory analysis of all data was performed with the Lilliefors (Lilliefors, 1967) tests to verify the normal distribution and the Bartlett homogeneity test using the Assistat statistical software. According to the results of the tests, the data of all the variables presented normal and homogeneous distribution. In sequence, the analysis of variance was performed, and for the results that showed significance, regression analysis was performed in function of irrigation levels and hydrogel doses, and the best fit was defined according to the combination of significance at 0.05 probability and higher coefficient of determination, using the statistical software SISVAR.

\section{Results AND Discussion}

The gravimetric moisture (GM) content of the soil corresponding to the doses of the hydrogel $0,50,100,150$ and 200 g were, respectively, $15.43 ; 15.33 ; 16.22 ; 17.47$ and $17.61 \%$. For irrigation levels 50,75, 100 and $125 \%$, the means of GM were $15.78 ; 15.82 ; 16.55$ and $17.33 \%$, respectively. According to the results of the means found, there was an increase in the percentage of moisture, both with increasing dose of the hydro retainer solution $(2.18 \%)$, as well as with increasing level of irrigation (1.55\%).

This behavior is indicative of the contribution of the treatments used in relation to the maintenance of soil moisture. A factor of paramount importance for vegetables, which have a relatively superficial root system and demand high water availability.

Similar data were observed by Mendonça et al. (2015), which indicate that in a soil with $300 \mathrm{~g}$ of hydrogel solution per well (dilution $4 \mathrm{~g} \mathrm{~L}^{-1}$ ), its moisture was greater in relation to the soil without hydrogel. In this experiment, the presence of hydrogel also promoted an increase of GM when a dose equal to or greater than $100 \mathrm{~g} \mathrm{plant}^{-1}$ was used.

Data referring to the accumulated values obtained in the experimental period for irrigation levels of 50,75, 100 and $125 \%$ of the evaporation (EV) were, respectively, 54.68; $67.03 ; 79.39$ and $91.75 \mathrm{~mm}$. These values are inferior to those found in the literature. Valeriano et al. (2016), with a $100 \%$ ETc replacement, used a irrigation depth of $123.52 \mathrm{~mm}$ in a lettuce crop cycle with 66 DAT. For Silva \& Queiroz (2013), the irrigation depth corresponding to $100 \%$ replacement of EV in a protected environment was $121.19 \mathrm{~mm}$, with harvest at $45 \mathrm{DAT}$.

The accumulated lower irrigation depths obtained in this work can be explained, since the conduction period of the experiment was much lower than the other studies, being 
only 29 DAT. This occurred due to the high precocity of the cultivar of crisphead lettuce used. Another important point to note is the great temperature variation observed throughout the experiment, starting with low temperatures. This behavior may have accelerated its growth, besides the genetic material already favors precocity.

The irrigation levels used in the cultivation of lettuce had a significant effect $(p<0.05)$, for the variables: fresh mass of aerial part, height and yield, while the hydro retainer dose factor presented a significant response $(\mathrm{p}<0.01)$, for all variables. There was no interaction between levels of irrigation and doses of the hydro retainer solution ( $p>0.05)$ (Table 1).

The fact that there was no significant interaction between the irrigation levels and the hydro retainer solution, according to the findings of other authors. Lima et al. (2003) working with different irrigation depths and doses of hydroabsorbent polymer in the production of coffee seedlings, had similar results, as well as Fernandes et al. (2015), in the growth of passion fruit seedlings, under the effect of irrigation depths and the use of hydrogel.

Azambuja et al. (2015) evaluating the use of hydrogel and nitrogen doses, also did not obtain a significant effect of the interaction of the factors studied for any of the evaluated variables.

The fresh mass of the aerial part showed a linear response as a function of irrigation levels and quadratic response as a function of the irrigation levels (Figure 2A). By the regression study, there was an increase of $22.4 \%$ of the fresh mass of the aerial part compared to irrigation levels of 50 and $125 \%$.

These data corroborate the results found by Valeriano et al. (2016), which also observed significant differences between levels of irrigation in lettuce cultivation. However, these authors

Table 1. ANOVA summary for fresh mass of aerial part (FMAP), dry mass of aerial part (DMAP), number of leaves $(\mathrm{NL})$, plant height $(\mathrm{H})$ and productivity (PRO) of lettuce subjected to irrigation levels and doses of hydro retainer solution in a protected environment

\begin{tabular}{|c|c|c|c|c|c|c|}
\hline \multirow{2}{*}{$\begin{array}{c}\text { Source } \\
\text { of variation }\end{array}$} & \multirow{2}{*}{ DF } & \multicolumn{5}{|c|}{ Mean square } \\
\hline & & FMAP & DMAP & NL & $\bar{H}$ & PRO \\
\hline Block & 3 & $417.57^{\text {ns }}$ & $11.61^{*}$ & $7.52^{\text {ns }}$ & $13.91^{\text {ns }}$ & $3.70^{\text {ns }}$ \\
\hline Irrigation levels & 3 & $3637.31^{* *}$ & $2.98^{\text {ns }}$ & $14.37^{\mathrm{ns}}$ & $29.62^{* *}$ & $33.70^{* *}$ \\
\hline Residue a & 9 & 591.33 & 1.48 & 3.77 & 6.39 & 5.49 \\
\hline Doses & 4 & $4047.52^{*}$ & $10.31 *$ & $17.85^{*}$ & $25.02 *$ & $37.50^{*}$ \\
\hline Dose $\mathrm{x}$ irrigation levels & 12 & $411.78^{\text {ns }}$ & $1.00^{\text {ns }}$ & $1.68^{\text {ns }}$ & $1.50^{\text {ns }}$ & $3.76^{\text {ns }}$ \\
\hline Residue b & 48 & 280 & $0.57^{\text {ns }}$ & 1.32 & 1.66 & 5.57 \\
\hline CV a (\%) & 17.65 & 17.65 & 15.48 & 13.56 & 13.08 & 17.72 \\
\hline CV b (\%) & 12.15 & 12.15 & 9.33 & 8.04 & 6.66 & 12.11 \\
\hline Irrigation & \multicolumn{6}{|c|}{ Mean } \\
\hline levels & \multicolumn{4}{|c|}{ (g) } & (cm) & $\left(t h a^{-1}\right)$ \\
\hline 50 & & 123.25 & 7.79 & 13.91 & 18.00 & 11.83 \\
\hline 75 & & 129.51 & 7.80 & 14.01 & 18.56 & 12.44 \\
\hline 100 & & 151.20 & 8.45 & 15.59 & 20.44 & 14.53 \\
\hline 125 & & 147.06 & 8.48 & 13.78 & 20.25 & 14.12 \\
\hline \multirow{2}{*}{ Doses } & \multicolumn{6}{|c|}{ Mean } \\
\hline & & (g) & & & (cm) & $\left(t h a^{-1}\right)$ \\
\hline 0 & & 112.54 & 6.88 & 12.77 & 17.49 & 10.80 \\
\hline 50 & & 131.32 & 7.75 & 13.74 & 18.62 & 12.61 \\
\hline 100 & & 147.80 & 8.69 & 15.38 & 19.77 & 14.19 \\
\hline 150 & & 148.85 & 8.62 & 14.84 & 20.59 & 14.31 \\
\hline 200 & & 148.29 & 8.70 & 14.89 & 20.09 & 14.24 \\
\hline
\end{tabular}

CV - Coefficient of variation; ns, ${ }^{*}$ and ${ }^{* *}$ Not significant, significant at 0.05 and 0.01 , respectively, by the $\mathrm{F}$ test

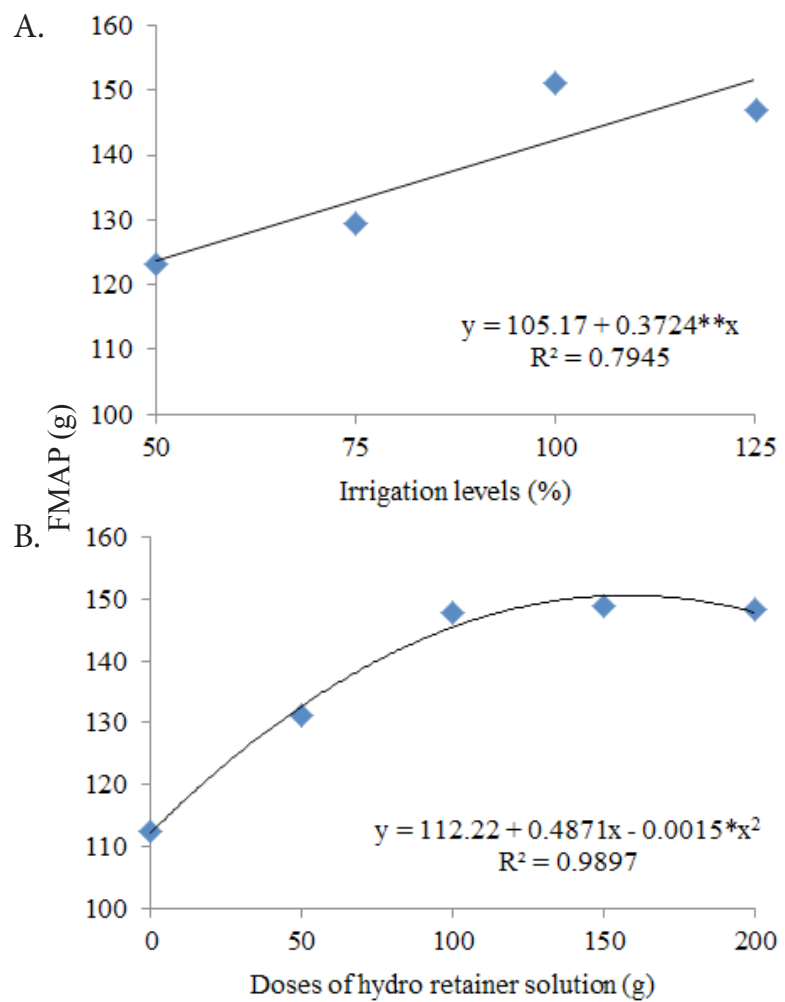

Figure 2. Fresh mass of the aerial part (FMAP) as a function of irrigation levels (A) and of doses of hydro retainer solution (B), in the cultivation of lettuce in a protected environment

found a quadratic behavior, with the maximum efficiency for this variable being $94 \%$ of the crop evapotranspiration (ETc).

Vilas Boas et al. (2007) verified that two cultivars of crisphead lettuce (Veronica and Hortência) responded similarly to different water replacements, and there was an increase in the total fresh mass of the aerial part, until the replacement of $125.8 \%$.

As for the use of hydrogel, for the variable fresh mass of the aerial part, it was verified that the lettuce plants reached the maximum value ( $151.76 \mathrm{~g}$ ) with a dose of $162.36 \mathrm{~g}$, an increase of $35.23 \%$ in relation to the dose 0 (Figure 2B). Santos et al. (2015) working with four doses of hydrogel per pot $(0,8,16$ and $24 \mathrm{~g}$ ), in the cultivation of lettuce in pots with sandy soil, verified that plants cultivated under a dose of $16 \mathrm{~g}$ showed superiority in the fresh mass and dry mass of the aerial part (shoot), and at a dose of $24 \mathrm{~g}$ the results decreased.

The quadratic characteristic presented in the work of these authors for the variables fresh mass of aerial part and dry mass of aerial part, may have occurred by the accumulation of moisture in the soil, because according to Nobre et al. (2009), a high water content in the soil negatively influences the accumulation of phytomass in the lettuce crop.

In the present study, the highest value of dry mass of the aerial part $(8.86 \mathrm{~g})$ was estimated at a dose of $169.28 \mathrm{~g}$ of solution, resulting in an increment of $29.24 \%$ of this variable in relation to the dose 0 (Figure $3 \mathrm{~A}$ ).

For the number of leaves, the regression analysis of the results also presented adjustment with a quadratic equation in relation to the doses of hydro retainer used (Figure 3B). The estimated dose of $168.5 \mathrm{~g}$ of hydro retainer solution generated an increase of $22.39 \%$ in the number of leaves in relation to the 

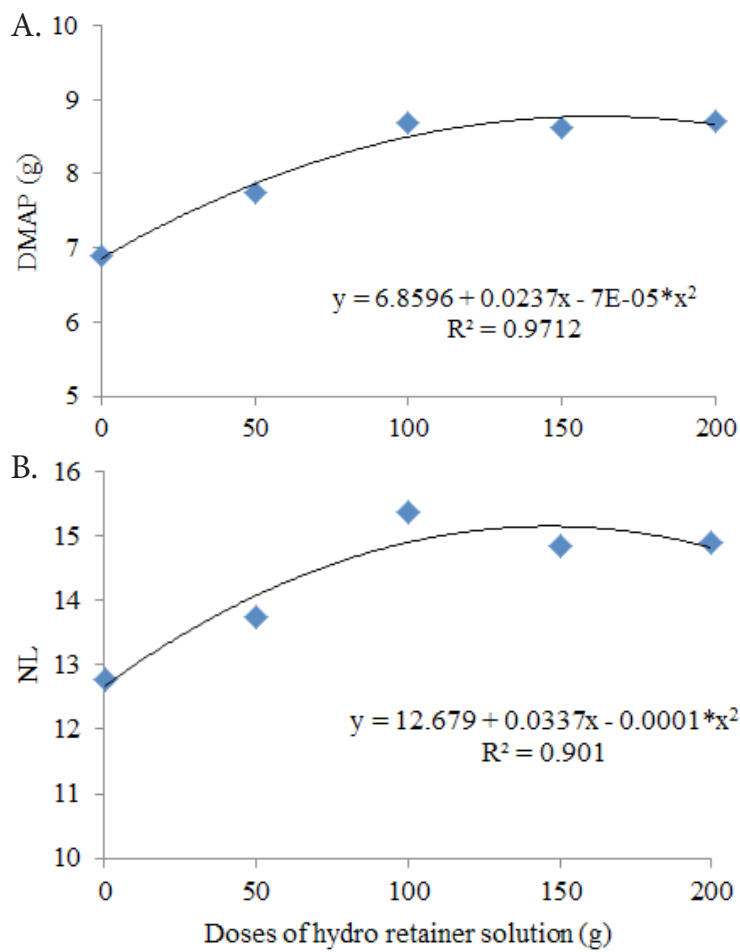

Figure 3. Dry mass of aerial part (DMAP) (A) and number of leaves (NL) (B) as a function of doses of hydro retainer solution in the cultivation of lettuce in a protected environment

dose 0 g. Oliveira et al. (2014) evaluating the performance of lettuce 'Mimosa Roxa' in face of different nitrogen and hydrogel doses, did not verify the influence of using hydrogel on the variable number of leaves.

For the regression analysis of the plant height values, a linear and quadratic responses were obtained for the factors irrigation levels and hydro retainer doses, respectively (Figure 4). Comparing the irrigation levels of 50 and $125 \%$, there was an increase of $14.3 \%$ of plant height (Figure $4 \mathrm{~A}$ ).

For doses, the regression equation showed that under the dose of $169.41 \mathrm{~g}$, plant height reached a maximum value of $20.32 \mathrm{~cm}$, increase of $17.0 \%$ in relation to the dose 0 (Figure 4B). Azambuja et al. (2015) also found a higher plant height of Caserta zucchini plants when they performed the application of hydrogel on the occasion of sowing.

The linear regression model was also the best fit for the variable yield, for the factor irrigation levels and for the solution dose factor, the appropriate model was the quadratic (Figure 5).

For productivity, the comparison of irrigation levels of 50 and $125 \%$ showed an increase of $22.6 \%$ (Figure 5A). The maximum point of expression of the dose factor was achieved using $157.49 \mathrm{~g}$ of the hydro retainer, generating a productivity of $14.46 \mathrm{t} \mathrm{ha}^{-1}$, an increase of $34.25 \%$ in relation to the mean obtained with the dose 0 (Figure 5B).

The increasing linear response of lettuce yield as a function of irrigation levels, was also observed by Araújo et al. (2010), when working with the lettuce cultivar Verônica from the crisphead group in a protected environment, in Boa Vista, Roraima state, Brazil, achieved a yield of $17.35 \mathrm{t} \mathrm{ha}^{-1}$, with an evaporation level of $120 \%$ of the Class A tank. According to these authors, low productivity is related to local climatic conditions, with a mean temperature value of $31.9{ }^{\circ} \mathrm{C}$.

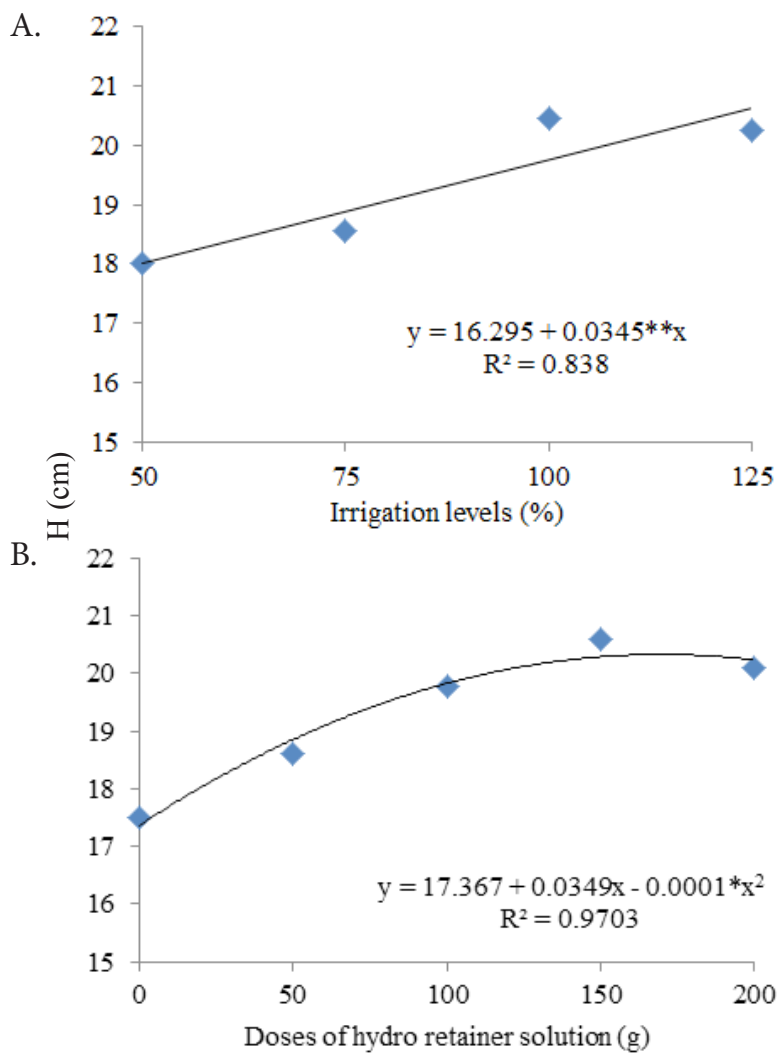

Figure 4. Plant height $(\mathrm{H})$ as a function of irrigation levels $(\mathrm{A})$ and of doses of hydro retainer solution (B) in the cultivation of lettuce in a protected environment

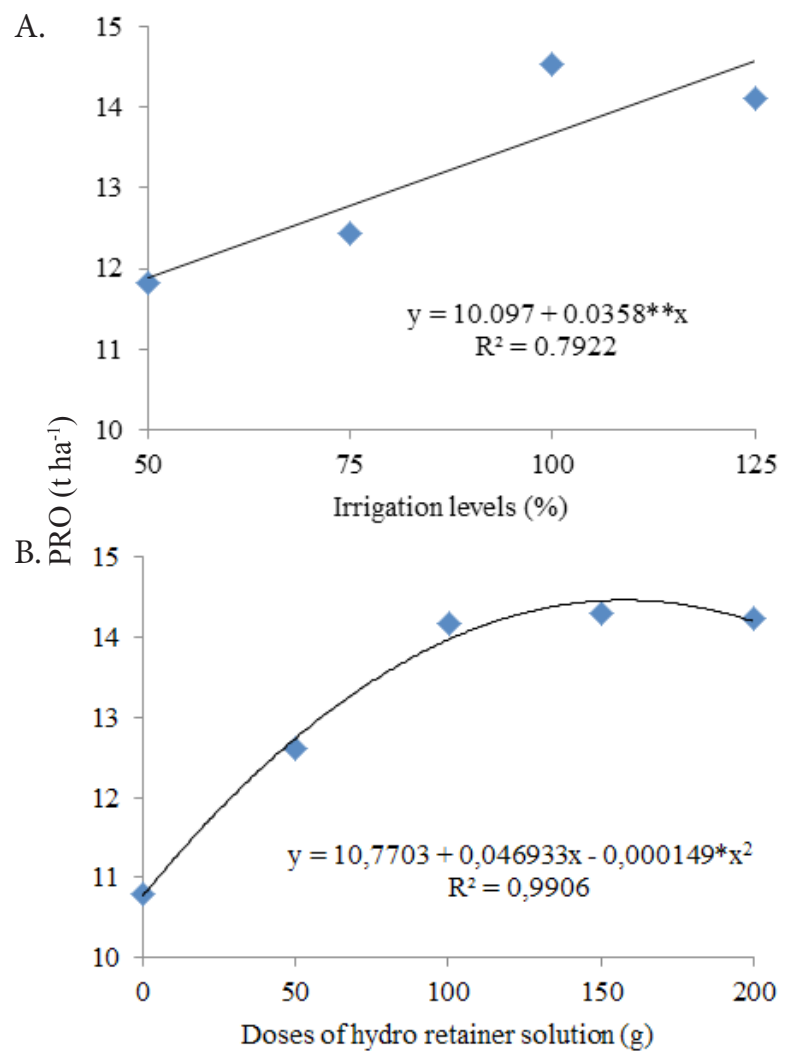

Figure 5. Productivity (PRO) as a function of irrigation levels (A) and of doses of hydro retainer solution (B), in the cultivation of lettuce in a protected environment

For other authors (Andrade Junior \& Klar, 1997; Vilas Boas et al., 2008; Lima Júnior et al., 2010), the response of lettuce productivity as a function of irrigation levels was quadratic. 
Lima Júnior et al. (2012), with a 95\% replacement factor of Class A tank evaporation, obtained maximum productivity for the American lettuce.

\section{Conclusions}

1. The use of hydro retainer solution in crisphead lettuce, cultivar Vanda, provided a significant increase in all the productive variables.

2. The irrigation levels used significantly influenced the variables fresh mass of aerial part, plant height and productivity.

3. The productivity increased $22.6 \%$ for the irrigation levels used and the highest estimated values were obtained with hydro retainer solution dose of $157.49 \mathrm{~g}\left(14.46 \mathrm{t} \mathrm{ha}^{-1}\right)$.

\section{Literature Cited}

Andrade Júnior, A. S. de; Klar, A. E. Manejo da irrigação da cultura da alface (Lactuca sativa L.) através do tanque classe A. Scientia Agrícola, v.54, p.31-38, 1997. http://dx.doi.org/10.1590/S010390161997000100005

Araújo, W. F.; Souza, K. T. S. de; Viana, T. V. de A.; Azevedo, B. M.; Oliveira, G. A. Rendimento e eficiência do uso da água pela alface em função da lâmina de irrigação. Revista Caatinga, v.23, p.115-120, 2010.

Azambuja, L. O.; Benett, C. G. S.; Benett, K. S. S.; Costa, E. Produtividade da abobrinha 'Caserta' em função do nitrogênio e gel hidrorretentor. Científica, v.43, p.353-358, 2015. http://dx.doi. org/10.15361/1984-5529.2015v43n4p353-358.

Bartlett, M. S. Properties of sufficiency and statistical tests. Proceedings of the Royal Society of London, v.160, p.268-282, 1937. https://doi.org/10.1098/rspa.1937.0109

Carvalho, J. da S. Produção de pimenta dedo-de-moça em função de doses de hidrogel e turnos de irrigação. Ceres: Instituto Federal Goiano, 2017. 42p. Dissertação Mestrado

Fernandes, D. A.; Araújo, M. M. V.; Camili, E. C. Crescimento de plântulas de maracujazeiro-amarelo sob diferentes lâminas de irrigação e uso de hidrogel. Revista de Agricultura, v.90, p.229236, 2015.

Filgueira, F. A. R. Novo manual de olericultura: Agrotecnologia moderna na produção e comercialização de hortaliças. 3.ed. Viçosa: Editora da UFV, 2008. 421p.

Henz, G. P.; Suinaga, F. Tipos de alface cultivados no Brasil. Brasília: Embrapa Hortaliças, 2009. 7p. Comunicado Técnico, 75

Lilliefors, H. W. On the Kolmogorov-Smirnov test for normality with mean and variance unknown. Journal of the American Statistical Association, v.62, p.399-402, 1967. https://doi.org/10.1080/0162 1459.1967.10482916

Lima, L. M. L. de; Teodoro, R. E. F.; Fernandes, D. L.; Carvalho, H. de P.; Mendonça, F. C.; Carvalho, J. O. M. de. Produção de mudas de café sob diferentes lâminas de irrigação e doses de um polímero hidroabsorvente. Bioscience Journal, v.19, p.27-30, 2003.

Lima Júnior, J. A. de; Pereira, G. M.; Geisenhoff, L. O.; Costa, G. G.; Vilas Boas, R. C.; Yuri, J. E. Efeito da irrigação sobre o rendimento produtivo da alface americana, em cultivo protegido. Revista Brasileira de Engenharia Agrícola e Ambiental, v.14, p.797-803, 2010. https://doi.org/10.1590/S1415-43662010000800002
Lima Júnior, J. A. de; Pereira, G. M.; Geisenhoff, L. O.; Vilas Boas, R. C.; Silva, W. G. da; Silva, A. L. P. da. Produtividade da alface americana submetida a diferentes lâminas de irrigação. Semina: Ciências Agrárias, v.33, p.2681-2688, 2012. https://doi.org/10.5433/16790359.2012v33Supl1p2681

Marouelli, W. A.; Silva, W. L. de C. e; Silva, H. R. da. Manejo da irrigação em hortaliças. Brasília: Embrapa Hortaliças, 1996. 72p.

Mendonça, T. G.; Querido, D. C. M.; Sousa, C. F. Eficiência do polímero hidroabsorvente na manutenção da umidade do solo no cultivo de alface. Revista Brasileira de Agricultura Irrigada, v.9, p.239-245, 2015. https://doi.org/10.7127/rbai.v9n400312

Navroski, M. C.; Araújo, M. M.; Fior, C. S.; Cunha, F. da S.; Berghetti, A. L. P.; Pereira, M. de O. Uso de hidrogel possibilita redução da irrigação e melhora o crescimento inicial de mudas de Eucalyptus dunnii Maiden. Scientia Forestalis, v.43, p.467-476, 2015.

Nobre, R. G.; Fernandes, P. D.; Gheyi, H. R.; Brito, M. E. B.; Silva, L. A. da. Crescimento da alface sob saturação temporal do solo. Revista Brasileira de Engenharia Agrícola e Ambiental, v.13, p.890-898, 2009. https://doi.org/10.1590/S1415-43662009000700011

Oliveira, G. Q. de; Biscaro, G. A.; Jung, L. H.; Araújo, E. de O.; Vieira Filho, P. S. Fertirrigação nitrogenada e níveis de hidrogel para a cultura da alface irrigada por gotejamento. Engenharia na Agricultura, v.22, p.456-465, 2014.

Sala, F. C.; Costa, C. P. da. Retrospectiva e tendência da alfacicultura brasileira. Horticultura Brasileira, v.30, p.187-194, 2012. https:// doi.org/10.1590/S0102-05362012000200002

Salomão, L. C. Calibração de tanques evaporímetros de baixo custo sob diferentes diâmetros em ambiente protegido. Botucatu: UNESP, 2012. 87p. Tese Doutorado

Santos, H. T. dos; Carvalho, D. F. de; Souza, C. F.; Medici, L. O. Cultivo de alface em solos com hidrogel utilizando irrigação automatizada. Engenharia Agrícola, v.35, p.852-862, 2015. https:// doi.org/10.1590/1809-4430-Eng.Agric.v35n5p852-862/2015

Santos, S. R. dos; Pereira, G. M. Comportamento da alface americana sob diferentes tensões da água no solo, em ambiente protegido. Engenharia Agrícola, v.24, p.569-577, 2004. https://doi. org/10.1590/S0100-69162004000300009

Silva, V. D. da; Queiroz, S. O. P. de. Manejo de água para produção de alface em ambiente protegido. Irriga, v.18, p.184-199, 2013. https://doi.org/10.15809/irriga.2013v18n1p184

Suinaga, F. A.; Boiteux, L. S.; Cabral, C. S.; Rodrigues, C. da S. Efeitos do calor e fontes tolerância ao florescimento precoce em variedades de alface do tipo americana. Brasília: Embrapa Hortaliças, 2013. 4p. Comunicado Técnico, 88

Trani, P. E.; Purqueiro, L. F. V.; Figueiredo, G. J. B.; Blat, S. F.; Costa, C. P. Alface. In: Aguiar, A. T. da E.; Gonçalves, C.; Paterniani, M. E. A. G. Z.; Tucci, M. L. S.; Castro, C. E. F. de. (eds.). Instruções agrícolas para as principais culturas econômicas. 7.ed. rev. atual. Campinas: Instituto Agronômico de Campinas, 2014. 452p. Boletim Técnico, 200

Trani, P. E.; Tivelli, S. W.; Carrijo, O. A. Fertirrigação em hortaliças. 2.ed. rev. atual. Campinas: Instituto Agronômico de Campinas, 2011. 51p. Boletim Técnico, 196

Valeriano, T. T. B.; Santana, M. J. de; Oliveira, A. F.; Machado, L. J. M. Alface americana cultivada em ambiente protegido submetida a doses de potássio e lâminas de irrigação. Irriga, v.21, p.620-630, 2016. https://doi.org/10.15809/irriga.2016v21n3p620-630 
Vilas Boas, R. C.; Carvalho, J. de A.; Gomes, L. A. A.; Sousa, A. M. G. de.; Rodrigues, R. C.; Souza, K. J. de. Avaliação técnica e econômica da produção de duas cultivares de alface tipo crisped em função de lâminas de irrigação. Ciência e Agrotecnologia, v.32, p.525-531, 2008. https://doi.org/10.1590/ S1413-70542008000200028
Vilas Boas, R. C.; Carvalho, J. de A.; Gomes, L. A. A.; Souza, K. J. de; Rodrigues, R. C.; Sousa, A. M. G. de. Efeito da irrigação no desenvolvimento da alface crespa, em ambiente protegido, em Lavras, MG. Revista Brasileira de Engenharia Agrícola e Ambiental, v.11, p.393-397, 2007. https://doi.org/10.1590/S141543662007000400008 